\title{
School-leavers: schooling, job level and wages
}

Citation for published version (APA):

Wieling, M. (1991). School-leavers: schooling, job level and wages. Researchcentrum voor Onderwijs en Arbeidsmarkt, Faculteit der Economische Wetenschappen. ROA Research Memoranda No. 6E https://doi.org/10.26481/umaror.199106E

Document status and date:

Published: 01/01/1991

DOI:

10.26481/umaror.199106E

Document Version:

Publisher's PDF, also known as Version of record

\section{Please check the document version of this publication:}

- A submitted manuscript is the version of the article upon submission and before peer-review. There can be important differences between the submitted version and the official published version of record.

People interested in the research are advised to contact the author for the final version of the publication, or visit the DOI to the publisher's website.

- The final author version and the galley proof are versions of the publication after peer review.

- The final published version features the final layout of the paper including the volume, issue and page numbers.

Link to publication

\footnotetext{
General rights rights.

- You may freely distribute the URL identifying the publication in the public portal. please follow below link for the End User Agreement:

www.umlib.nl/taverne-license

Take down policy

If you believe that this document breaches copyright please contact us at:

repository@maastrichtuniversity.nl

providing details and we will investigate your claim.
}

Copyright and moral rights for the publications made accessible in the public portal are retained by the authors and/or other copyright owners and it is a condition of accessing publications that users recognise and abide by the legal requirements associated with these

- Users may download and print one copy of any publication from the public portal for the purpose of private study or research.

- You may not further distribute the material or use it for any profit-making activity or commercial gain

If the publication is distributed under the terms of Article $25 \mathrm{fa}$ of the Dutch Copyright Act, indicated by the "Taverne" license above, 
SCHOOL-LEAVERS: SCHOOLING, JOB LEVEL

AND WAGES

ROA-RM-1991/6E

Myra Wieling

Paper presented at the Third Conference of the European Association of Labour Economists (EALE), El Escorial, Spain, 26th - 29th September, 1991.

RESEARCH CENTRE FOR EDUCATION AND LABOUR MARKET

Faculty of Economic Sciences

Rijksuniversiteit Limburg

Maastricht, August 1991 


\section{CIP-GEGEVENS KONINKLIJKE BIBLIOTHEEK, DEN HAAG}

Wieling, Myra

School-leavers: schooling, job level and wages / by Myra Wieling. - Maastricht: Research Centre for Education and Labour Market, Faculty of Economic Sciences, Rijksuniversiteit Limburg. (Research memorandum / Researchcentrum voor Onderwijs en Arbeidsmarkt ; 1991/6E)

Met lit. opg.

ISBN 90-5321-064-4 in spiraalband

Trefw.: schoolverlaters. 
CONTENTS

ABSTRACT

1. INTRODUCTION 1

$\begin{array}{lr}2 . & 4\end{array}$

3. MODEL SPECIFICATION 9

$\begin{array}{ll}\text { 4. RESULTS } & 13\end{array}$

5. SUMMARY AND CONCLUSIONS 19

$\begin{array}{ll}\text { REFERENCES } & 21\end{array}$

APPENDIX A: DESCRIPTION OF THE VARIABLES

APPENDIX B: ORDERED PROBIT MODEL 


\section{ABSTRACT}

This study focuses on the effects of schooling on the situation of school-leavers on the labour market. If the effect of schooling on earnings and job level increases gradually as each additional year of schooling is attended, the human capital theory is supported. In this case, the difference in earnings or job levels among graduates and drop-outs in the last year of schooling must be minor. However, if this difference is considerable, there is a strong tendency toward the acceptance of the screening theory. According to the screening and the signaling theory, diplomas have a dominant effect on both job allocation and earnings. To test the labour queue hypothesis, the question of whether the wage level of school-leavers in employment can be explained by the job characteristics of school-leavers is examined.

This paper considers the case of school-leavers from four types of education: higher economic schooling, higher technical schooling, intermediate economic schooling and intermediate technical schooling. For each educational type, two equations have been estimated in order to examine the effects of schooling on net monthly wages and on the job levels of employed school-leavers.

On the basis of the estimates calculated in this paper, it is concluded that the labour queue theory is only supported partially, since for all educational types distinguished, earnings are partly explained by the various job levels of school-leavers. Furthermore, the results relating to higher technical schooling, intermediate economic schooling and intermediate technical schooling show that the longer the period of time between interrupting education and the point at which a diploma would potentially have been obtained, the lower the job level and the lower the net monthly income of school-leavers. It could therefore be concluded that the human capital theory is supported for these educational types.

I would like to extend my thanks to Ed Willems, Andries de Grip, Gerard Pfann, Hans Heijke and Lex Borghans for their helpful advice and comments. 


\section{INTRODUCTION}

The human capital theory as well as the screening and the labour queue theories assume that individuals attempt to complete schooling ${ }^{1}$ at the highest possible level in order to improve their future position on the labour market. However, the basic hypotheses of these theories differ. The hypothesis implicit in the human capital theory states that schooling is productivityaugmenting (Schultz, 1961). According to this theory, a person's productivity increases as he or she attends more schooling. This results in more highly educated people receiving a higher income since, according to the human capital theory, income equals marginal productivity. By investing in schooling, individuals can thus enlarge their productivity and therefore gain higher incomes. The decision to attend additional schooling depends, on the one hand, on the (direct and indirect) costs of this schooling and, on the other, on the expected increase in future income as a result of this additional schooling.

As in the case of the human capital theory, the screening theory assumes that the income an individual receives depends on the schooling attended. However, the screening theory focuses on the information generated on individuals by this schooling. The basic assumption of the screening theory is that individuals who are more highly educated signal higher capabilities and are therefore considered to be more productive than less skilled persons (Stiglitz, 1975). However, individual productivity cannot be distinguished before employment is actually entered into. According to the screening theory, graduation has a dominant effect, whereas the human capital theory maintains that the effect of schooling on future productivity builds up gradually for each year education is attended. In other words, according to the screening theory, schooling only reveals the capabilities available by signaling that one is able to graduate at a particular level. Contrary to the human capital theory, the screening theory assumes that, in the case of schooling which is prematurely interrupted, the years of schooling attended prior to dropping out should be considered as useless.

The screening theory considers the sorting of the labour supply from the employer's point of view. This kind of sorting can be supplemented by sorting from the point of view of the employee, this being supported by the signaling theory (Spence, 1973). The signaling theory emphasizes the fact that the individual's productive abilities are not known to employers. However, workers themselves are aware of their own abilities, and it is on the basis of this knowledge that individuals choose their education in order to reveal their abilities to the employer.

1. It should be noted that in this study the terms schooling and education will be used arbitrarily. It is assumed that both terms represent the educational types distinguished in this paper. 
It should be noted that the difference between the screening and the signaling theory is not a subject of this study, since it is not possible to test which of these two theories has an effect on earnings and job levels. For this reason, for the remainder of this paper, only the screening theory will be referred to.

Thurow (1979) gives a different explanation of the screening hypothesis: the labour queue theory. This theory assumes that for practising a profession specific knowledge and skills are required. These skills are not acquired through schooling but by means of on-the-job training, which also involves costs. On the basis of these educational costs, employers classify workers by applying a labour queue. However, the necessary educational costs cannot be perceived before an individual actually enters employment. The labour queue is therefore determined on the basis of diplomas obtained. As stated in the screening theory, the labour queue theory assumes that schooling is only capable of revealing qualifications and that it adds nothing to a worker's productivity. More highly educated individuals are easier to train than those who are less educated and, therefore, the costs involved in educating the former group will be lower. As a consequence of this, those workers at the front of the labour queue are more likely to be eligible for an employment vacancy.

This study focuses on the effects of initial schooling on the labour market. The question of whether a diploma has a dominant effect on both job allocation and income, according to the screening theory, or whether this effect gradually increases for each year of schooling attended, according to the human capital theory (Hartog, 1983), will be examined. If the human capital hypothesis is supported, the difference in earnings or job levels among graduates and drop-outs from the last year of schooling must be minor (Groot and Oosterbeek, 1990). If, on the other hand, this difference is considerable, there is a strong tendency towards the acceptance of the screening theory. This study also attempts to test Thurow's labour queue hypothesis: only if the incomes of employed school-leavers can be explained by the job characteristics of these school-leavers, do the results support the labour queue theory.

This paper examines the labour market performance of school-leavers from four types of vocational education: higher economic schooling, higher technical schooling, intermediate economic schooling and intermediate technical schooling (in the Netherlands these educational types are respectively abbreviated with HEAO, HTS, MEAO and MTS). For each educational type, two equations have been estimated in order to examine the effects of schooling on the incomes and job levels of employed school-leavers. This distinction between job allocation and earnings is based on the fact that the determination of individual earnings occurs in two stages (Hartog, 1983). The first is the allocation of individuals to employment and the second is the payment of these individuals within such employment. The independent variables in these 
equations are the individual schooling characteristics and personal characteristics.

Although not directly linked to one of the labour market theories mentioned here, another focal point is the influence of a school-leaver's educational career on incomes and job levels. The school-leavers examined in this paper have all attended vocational education. For this reason, the effect on job allocation and earnings of the types of education completed by these schoolleavers prior to entering their last-attended school, is also examined. A distinction can be made between, on the one hand, general human capital and, on the other, job-specific human capital. General education stresses general qualifications, while vocational education emphasizes jobspecific qualifications. Furthermore, the types of education completed by the school-leavers prior to entering their last-attended school imply differences in the numbers of years that the school-leavers have already spend in education.

The structure of this paper is as follows. Section 2 describes the data used in this study. A specification of the equations to be estimated is given in section 3 . In section 4 the results of the estimated equations are discussed. Finally, in section 5, a summary of the estimation results is given and several conclusions are drawn on the basis of the feedback provided by the estimation results to the labour market theories. 


\section{DATA}

In order to examine the problems formulated, data obtained from a large Dutch school-leavers survey entitled 'Registration of Outflow and Destination of School-leavers' (Registratie van Uitstroom en Bestemming van Schoolverlaters (RUBS)) has been used. This postal survey examines the situation of school-leavers approximately one year after leaving school (regardless of whether a diploma had been obtained or not). This study concentrates on school-leavers of intermediate and higher vocational education. Furthermore, a selection has been made with respect to the types of schooling included in the analysis, namely those focusing on economic and technical education. As a result of this, four educational types have been selected: higher economic schooling, higher technical schooling, intermediate economic schooling and intermediate technical schooling.

The sample used contains a total of 1,167 school-leavers, after eliminating those individuals for which certain observations were missing, and selecting only those school-leavers in full-time employment (working more than 32 hours weekly). The four types of education distinguished in this paper contain, respectively, 103, 117, 546 and 401 school-leavers. It should be noted that the number of observations with regard to the higher economic and technical educational types is rather low.

The explanatory variables selected refer to age, sex (a dummy equal to 1 for females), region (a dummy equal to 1 for non-residence in the economic centre of the Netherlands, the 'Randstad'), ethnic minority (a dummy equal to 1 for second-generation immigrants) and employment status (a dummy equal to 1 for temporary employment and a dummy equal to 1 for the pursuit of selfemployment). Other explanatory variables refer to education. The survey poses the question of whether a diploma was obtained and, if not, investigates how many years before graduation education was interrupted. This latter variable is defined here as the 'graduation gap' in the case of each corresponding educational level; this gap is measured in years. For school-leavers who obtained a diploma from the school which they attended last, this gap is, by definition, equal to zero.

Furthermore, this study also considers the educational type which school-leavers completed before entering the education which they last attended. There are four groups of previous schooling relating to the four educational types distinguished in this study: general schooling at a level that meets the minimum requirements, general schooling of a higher than required level, corresponding vocational education of a lower level than the last educational type and a variable 
indicating any other type of education ${ }^{2}$. A school-leaver from one of the two types of higher vocational education may have previously completed general schooling of a higher or intermediate level. Moreover, a school-leaver from higher economic schooling may have previously studied at an intermediate economic school, while a school-leaver from higher technical schooling may have previously studied at an intermediate technical school. A schoolleaver from intermediate vocational schooling may, prior to this last educational type, have completed general schooling of a lower, intermediate or higher level (for intermediate vocational education, these latter two types of general schooling are combined). However, these schoolleavers may have also completed a form of vocational education in the same branch of study at a lower level. The category 'other previous schooling' refers to all types of education which are not directly linked to the last-attended educational type.

The dependent variables used are job level and earnings. Since the exact number of hours which a school-leaver works are not known, this study chooses to express earnings as the net monthly wage rate. In order to avoid the necessity of including the weekly number of hours which a school-leaver works in the regression, only those school-leavers who, at the time of the survey, were in full-time employment (i.e. more than 32 hours a week) were selected.

Job level is defined as the level associated with an individual's job. These levels are obtained from Huijgen (1989). To this end, Huijgen applied a 7-point scale. Level 1 is referred to as 'very simple work', and level 7 as 'scientific work'. In order to determine a job's score on this scale, jobs are analyzed according to their degree of complexity. This score is therefore intended to indicate the level of intellectual ability and knowledge required for a certain job.

On the basis of the job level of a school-leaver defined at the time of the survey, it can be determined whether the school-leaver finds himlherself in a situation of over-education. It should be noted that over-education can only be determined unambiguously for school-leavers who obtained their diploma. Over-education occurs when a school-leaver's job level is lower than the level of schooling he or she has completed. For graduates of higher vocational education, over-education means that the job levels are lower than that of level 5. Graduates of intermediate vocational schooling who have job levels lower than that of level 4 are also considered to be in a situation of over-education.

Table 1 presents the means and the standard deviations for all the variables taken into account for the purposes of this study. Almost all variables mentioned in Table 1 are dummy variables;

2. The Dutch abbreviations of the corresponding educational types are mentioned in Appendix A. 
the only exceptions are age, earnings, job level and graduation gap.

Table 1. The means and standard deviations for the variables

\begin{tabular}{|c|c|c|c|c|c|c|c|c|}
\hline \multirow[t]{2}{*}{ variables } & \multicolumn{2}{|c|}{$\begin{array}{l}\text { higher } \\
\text { economic } \\
\text { schooling }\end{array}$} & \multicolumn{2}{|c|}{$\begin{array}{l}\text { higher } \\
\text { technical } \\
\text { schooling }\end{array}$} & \multicolumn{2}{|c|}{$\begin{array}{l}\text { intermediate } \\
\text { economic } \\
\text { schooling }\end{array}$} & \multicolumn{2}{|c|}{$\begin{array}{l}\text { intermediate } \\
\text { technical } \\
\text { schooling }\end{array}$} \\
\hline & $\mu$ & $\sigma$ & $\mu$ & $\sigma$ & $\mu$ & $\sigma$ & $\mu$ & $\sigma$ \\
\hline \multicolumn{9}{|l|}{ personal characteristics } \\
\hline region & 0.00 & 0.00 & 0.00 & 0.00 & 0.34 & 0.47 & 0.08 & 0.27 \\
\hline age & 23.29 & 1.45 & 24.27 & 1.86 & 20.26 & 1.15 & 22.09 & 2.07 \\
\hline sex & 0.49 & 0.50 & 0.04 & 0.20 & 0.76 & 0.42 & 0.04 & 0.20 \\
\hline ethnic minority & 0.01 & 0.10 & 0.01 & 0.09 & 0.01 & 0.10 & 0.02 & 0.12 \\
\hline \multicolumn{9}{|l|}{ job characteristics } \\
\hline self-employed & 0.01 & 0.10 & 0.03 & 0.18 & 0.01 & 0.10 & 0.03 & 0.16 \\
\hline temporary job & 0.26 & 0.44 & 0.27 & 0.44 & 0.25 & 0.43 & 0.24 & 0.43 \\
\hline earnings & 1935 & 254 & 2008 & 315 & 1332 & 290 & 1660 & 339 \\
\hline job level & 4.32 & 1.34 & 4.82 & 1.29 & 3.27 & 0.88 & 4.24 & 1.17 \\
\hline over-education & 0.61 & 0.49 & 0.30 & 0.46 & 0.65 & 0.48 & 0.12 & 0.32 \\
\hline \multicolumn{9}{|l|}{ educational characteristics } \\
\hline no diploma & 0.00 & 0.00 & 0.15 & 0.35 & 0.15 & 0.36 & 0.10 & 0.30 \\
\hline graduation gap & 0.00 & 0.00 & 0.47 & 1.20 & 0.27 & 0.72 & 0.27 & 0.89 \\
\hline \multicolumn{9}{|l|}{ previous schooling: } \\
\hline lower general & - & - & - & - & 0.63 & 0.48 & 0.43 & 0.50 \\
\hline intermediate general & 0.18 & 0.38 & 0.21 & 0.41 & $-\infty$ & $-\infty$ & - &. \\
\hline higher general & 0.68 & 0.47 & 0.27 & 0.45 & - & - & - & - \\
\hline intermediate or higher general & - & - & - & - & 0.31 & 0.46 & 0.11 & 0.31 \\
\hline lower economic & - & - & - & - & 0.04 & 0.18 & - & - \\
\hline lower technical & - & - & - & - & - & - & 0.36 & 0.48 \\
\hline intermediate economic & 0.15 & 0.35 & - & - & - & - & - & - \\
\hline intermediate technical & - & - & 0.37 & 0.48 & - & - & - & - \\
\hline other previous schooling & - & - & 0.15 & 0.35 & 0.03 & 0.18 & 0.11 & 0.31 \\
\hline $\mathrm{n}=$ & 103 & & 117 & & 546 & & 401 & \\
\hline
\end{tabular}

For a description of the variables, see Appendix A.

The first group of variables consists of the personal characteristics of school-leavers. With regard to region, it can be seen that, for higher vocational education, all school-leavers are from the economic centre of the Netherlands. The average age of school-leavers from the economic types of education is higher than for the technical types of schooling. As was expected, the average age is higher for school-leavers from higher vocational schooling than for school-leavers from intermediate vocational schooling. Sex is of importance mainly in the economic types of education. The percentage of females participating in these educational types amounts to about 
$50 \%$ for school-leavers from higher economic schooling and about $75 \%$ for school-leavers from intermediate economic schooling. With respect to technical education, females account for only $4 \%$ of school-leavers. The percentage of school-leavers belonging to ethnic minorities is very small in the case of both higher and intermediate economic and technical schooling.

The variables 'self-employed' and 'temporary job' refer to the group of variables representing job characteristics. The percentage of school-leavers who were self-employed at the time of the survey is very small. For all educational types distinguished, the percentage of school-leavers working on a temporary basis is about $25 \%$. The other variables belonging to this category are: net monthly wages, average job level and, deduced from the variable 'job level', the percentage of over-education. Average earnings in the case of both higher and intermediate vocational schooling are the highest for school-leavers from the technical type of education. As had been expected, the average earnings of school-leavers from higher vocational education are higher than the average earnings of school-leavers from intermediate vocational education. The same applies for average job levels: school-leavers from technical types of schooling have a higher average job level than those from the economic types of education, and school-leavers from higher vocational education have a higher average job level than those from intermediate education. The percentage over-education is determined in the case of the graduates of the four educational types distinguished in this paper. It may be observed that over-education is most frequent in the case of the economic types of schooling; $61 \%$ for higher economic education and $65 \%$ for intermediate economic education. In the case of technical education, overeducation amounts to $30 \%$ for higher technical education and $12 \%$ for intermediate technical education.

The third group of variables consists of the educational characteristics of school-leavers. With regard to school-leavers from higher economic education, no data is available on non-graduates. This implies that, with respect to the underlying sample, the average graduation gap for schoolleavers from higher economic schooling is zero. For the other types of education, non-graduates make up between $10 \%$ and $15 \%$ of respondents. The average graduation gap is the highest in the case of school-leavers from higher technical schooling (0.47). For all educational types, with the exception of higher economic schooling, the standard deviations for this variable are high.

Approximately two thirds of the school-leavers from higher economic schooling completed a form of higher general education before attending higher vocational education. In the case of intermediate economic education, almost two thirds of the school-leavers attended general secondary education (lower level) as previous schooling. With regard to technical education of a higher and intermediate level, the percentage of school-leavers having completed a form of technical education of a lower level than the last form of education attended is somewhat 
-8-

higher than in the case of higher vocational schooling. Finally, $43 \%$ of school-leavers from intermediate technical schooling completed lower general schooling before entering their lastattended form of education.

Before the equations that are to be estimated are specified, it should be stressed that this study focuses on workers having left education only one year previously. The time period elapsing between respondents leaving school and the collection of the survey data was therefore very short. Consequently, within the scope of this study, it has not been possible to account for a whole working career. 


\section{MODEL SPECIFICATION}

Before presenting the estimation results in section 4, this section describes the specification of the equations to be estimated. As already mentioned in section 1, this paper examines the labour market performance of school-leavers from four educational types: higher economic schooling, higher technical schooling, intermediate economic schooling and intermediate technical schooling. For each educational type, two equations have been estimated in order to examine the effects of schooling on the earnings and job levels of employed school-leavers.

Firstly, the job allocation equations have been estimated. The dependent variables for these estimates are the job levels of school-leavers. The explanatory variables are a number of personal characteristics, the job characteristics - permanent or temporary employment - and, finally, the educational characteristics - the graduation gap and the educational type completed before entering last-attended schooling.

Subsequently, the earnings equations have been estimated. For these equations, the net monthly wages of school-leavers are the dependent variables. The explanatory variables are a number of personal characteristics and the educational characteristics - the graduation gap and the educational type completed before entering last-attended schooling. In addition, the question of whether the school-leaver has a temporary or a permanent job is included as a job characteristic. Moreover, the job levels of school-leavers identified at the time of the survey are included in the earnings equations.

With regard to job levels, the following should be noted. Since very few school-leavers from intermediate vocational education have a job at level 7, the upper two levels (6 and 7) are combined. This means that there are actually only six levels distinguished in the two models concerning the effects of schooling on job levels for school-leavers from intermediate economic and technical schooling. In addition, there are few school-leavers from higher vocational education with jobs at levels 1 to 3 . Consequently, these job levels have also been combined to form one job level. There are thus only five job levels defined in the case of higher vocational education. As has already been pointed out, job level is included as an independent variable in the earnings equations. In these equations, the variable 'job level' is specified as a number of dummy variables. Furthermore, for each educational type distinguished, one job level has been chosen as the reference level. The reference job level is the 'normal' job level for school-leavers of the educational type concerned (i.e. the lowest job level at which there is no over-education). In the case of higher economic and technical education, the reference level is job level 5 . Job level 4 represents the reference job level for school-leavers from intermediate economic and technical schooling. As a result of this, in the case of higher and intermediate vocational 
education, respectively four and five dummies have been included as job level variables.

Table 2 presents the expected nature of the coefficients of the variables in the estimated equations (i.e. positive or negative values). The human capital theory assumes that graduating has no influence on job level and income. According to this theory job level and income increase gradually as more schooling is attended. The variable 'graduation gap' is therefore deduced from the fact whether school-leavers obtained a diploma and, if not how many years before graduation education was interrupted. If the coefficient of this variable is significantly less than zero, job levels and earnings are lower, as the period of time between interrupting education and the point at which the diploma would potentially have been obtained from last-attended schooling increases. This implies that job level and earnings increase gradually as more years of schooling are attended. In other words, if the graduation gap variable has a significantly negative influence, the human capital theory is supported with regard to the educational types distinguished in this paper.

The screening theory assumes that graduation has a dominant effect on job levels and incomes, and the years of schooling attended prior to dropping out are to be considered useless. This implies that if the screening theory is supported, the effect of obtaining the diploma from lastattended schooling on job level and income should be positive.

Table 2. Theoretical predictions

job level equation

earnings equation

human capital theory

no diploma

graduation gap

no influence

negative

no influence

negative

screening theory

no diploma

graduation gap

labour queue theory

job level below reference level job level above reference level negative

no influence

not included

not included negative

no influence

For a description of the variables, see Appendix A.

However, it should be noted that, in the job level and earnings equations, a dummy variable is not included for the diploma because such a variable would correlate highly with the graduation gap, since the latter variable is deduced from the variable 'no diploma'. Therefore the human 
capital theory will be supported in this paper, if the coefficient of the variable 'graduation gap' is significantly less than zero. Since, in this case job levels and earnings decrease gradually, as the period of time between interrupting education and the point at which the diploma would potentially have been obtained from last-attended schooling increases. If the graduation gap has no significant influence on job allocation and earnings, job levels and earnings do not increase gradually and the diploma has a dominant effect. In this case, the screening theory is supported.

As has already been mentioned, in the sample of school-leavers from higher economic schooling, all school-leavers obtained their diplomas, which means that, in the case of these school-leavers, the graduation gap is equal to zero. This implies that the variable 'graduation gap' should not be included in the estimated equations for these school-leavers.

In the job allocation equation, the job levels are the dependent variables. However, job levels are also included as explanatory variables in the earnings equations via a number of dummy variables. If these variables have a significant influence on net monthly wages, the labour queue theory is supported for the educational types distinguished in this paper. It is expected that the effect of job levels lower than the reference level will be negative, whereas the effect of job levels higher than the reference level is expected to be positive.

The question of whether or not school-leavers may be considered to be in a situation of overeducation, will not be included in the estimated equations. This variable is deduced from the corresponding job levels and therefore correlates with the job levels of school-leavers included in the analysis. Furthermore, whether or not school-leavers may be considered to be in a situation of over-education can only be determined unambiguously for school-leavers who obtained their diploma of last-attended education.

With respect to the other job characteristics, it may be observed that only a small number of the school-leavers examined are self-employed. This variable will therefore not be taken into account in the estimated equations. However, an additional variable which will be included in the equations is the question of whether or not school-leavers are in a situation of temporary employment.

With regard to the remaining variables mentioned in section 2, the following should be noted. Since only a small number of the school-leavers included in this study belong to ethnic minorities, the variable relating to ethnic minority has not been taken into account in the equations. The school-leavers from higher vocational schooling are all resident in the economic centre of the Netherlands. Therefore, the influence of the variable 'region' will only be 
estimated in the job level and earnings equations in the case of intermediate economic and intermediate technical schooling.

Contrary to several other studies (see e.g. Hartog, 1983), age will not be included as a nonlinear variable. The reason for this is that this paper focuses on the situation of workers having terminated their education only one year prior to the RUBS survey. This implies that the variable 'age' is likely to have only a small range. Therefore, the relationship between (1) job level and age and (2) earnings and age is assumed to be linear. Furthermore it should be noted that, the variable 'age' might correlate with the variable 'graduation gap', since school-leavers who drop out of education generally are younger than school-leavers who complete their education. However, this correlation does not seem to be present in the underlying sample, possibly because non-graduates may have repeated one or more classes.

In relation to the question of which educational type school-leavers completed before entering last-attended education, it should be observed that, in the case of higher vocational education, intermediate general schooling will be treated as the reference educational type. In the case of intermediate vocational education, lower general schooling has been chosen as the reference category. The sample of school-leavers from higher economic schooling all completed higher, intermediate general (reference variable) or intermediate economic schooling before entering last-attended education. 


\section{RESULTS}

This section presents the estimation results obtained and subsequently discusses the identified effects of schooling on job levels and earnings. The estimation results are given in Tables 3 and 4 respectively.

\section{Job level equation}

In order to examine the relationship between the different components of schooling and the allocation of jobs to individuals, an equation was estimated in which the dependent variable was the level of the job in which the school-leaver was employed at the time of the RUBS survey. The job level was measured on a 7-point scale on which level 1 represented the lowest level and level 7 the highest. Since in this case the dependent variable is ordinal, estimating by ordinary least squares gives biased estimates. Therefore, an ordered probit model was considered more appropriate for estimating the effect of schooling on job level (Maddala, 1983). For a more detailed description of the ordered probit model, see Appendix B (see also Hartog, 1988 and Greene, 1990). The results of the estimated job level equations are presented in Table $3^{3}$.

The estimation results presented in Table 3 show that none of the included variables have a significant influence on job level with regard to higher economic schooling. In the case of higher technical schooling, the effect of age is significant at the $5 \%$ level. The older the school-leaver, the greater the probability that he or she will be employed in a job of a relatively low level. As mentioned previously, $15 \%$ of the school-leavers from higher technical education left their lastattended school without having obtained a diploma. Consequently, the variable 'graduation gap' was taken into account in the case of this educational type. From the results presented in Table 3 , it appears that the graduation gap has a significantly (at the $5 \%$ level) negative influence. In other words, the larger the graduation gap, the greater the probability that the school-leaver obtains a job of a lower level.

With respect to intermediate economic schooling, it can be observed that region has a significantly negative effect on job level at the $5 \%$ level. This means that a school-leaver who does not live in the economic centre of the Netherlands has a higher probability that his or her

3. It should be noted that, the estimated values of the parameters in the ordered probit model cannot be directly interpreted. The extent of the increase or decrease in the probability of obtaining a higher job level is dependent on the 'basic' situation. Of course, the signs of the parameters are interpretable and enable us to test the theoretical predictions formulated in section 3 . 
job level will be lower than that of a school-leaver resident in the economic centre of the Netherlands. Age has a significantly positive effect on job level. The variable 'sex' is significantly larger than zero (at the $5 \%$ level). This implies that women have relatively high job levels compared to men. The variable 'temporary job' is significantly less than zero, which indicates that a school-leaver with a temporary job has a lower probability of obtaining a job of a higher level compared to a school-leaver with a permanent job. Because the graduation gap has a significantly negative effect, job level decreases as the graduation gap increases. In this case, the nature of previous schooling is irrelevant.

Table 3. The effects of schooling on job level (t-values in parenthesis)

\begin{tabular}{|c|c|c|c|c|c|c|c|c|}
\hline variables & \multicolumn{2}{|c|}{$\begin{array}{l}\text { higher } \\
\text { economic } \\
\text { schooling }\end{array}$} & \multicolumn{2}{|c|}{$\begin{array}{l}\text { higher } \\
\text { technical } \\
\text { schooling }\end{array}$} & \multicolumn{2}{|c|}{$\begin{array}{l}\text { intermediate } \\
\text { economic } \\
\text { schooling }\end{array}$} & \multicolumn{2}{|c|}{$\begin{array}{l}\text { intermediate } \\
\text { technical } \\
\text { schooling }\end{array}$} \\
\hline$a_{1}$ & 0.09 & $(0.06)$ & $-4.68^{* *}$ & $(-3.02)$ & 0.42 & $(0.49)$ & $-1.28^{* *}$ & $(-2.02)$ \\
\hline$a_{2}$ & 0.83 & $(0.48)$ & $-3.95^{\prime \prime}$ & $(-2.57)$ & 1.34 & $(1.57)$ & -0.68 & $(-1.08)$ \\
\hline$a_{3}$ & 1.39 & $(0.81)$ & $-2.96^{*}$ & $(-1.94)$ & $3.00^{* *}$ & $(3.50)$ & -0.33 & $(-0.52)$ \\
\hline$a_{4}$ & 1.93 & $(1.11)$ & -2.20 & $(-1.44)$ & $4.08^{* *}$ & $(4.73)$ & 0.94 & (1.50) \\
\hline$a_{5}$ & - & & - & & $4.80^{* *}$ & $(5.50)$ & $2.23^{* *}$ & (3.51) \\
\hline \multicolumn{9}{|l|}{ personal characteristics } \\
\hline region & - & & - & & $-0.46^{* *}$ & $(-4.48)$ & 0.06 & $(0.29)$ \\
\hline age & 0.03 & $(0.41)$ & $-0.14^{\prime *}$ & $(-2.19)$ & $0.13^{* *}$ & $(3.15)$ & 0.04 & (1.32) \\
\hline sex & -0.29 & $(-1.19)$ & 0.23 & $(0.46)$ & $0.23^{* *}$ & $(1.96)$ & -0.12 & $(-0.47)$ \\
\hline \multicolumn{9}{|l|}{ job characteristics } \\
\hline temporary job & 0.12 & $(0.50)$ & -0.17 & $(-0.76)$ & $-0.22^{* *}$ & $(-2.04)$ & 0.07 & $(0.55)$ \\
\hline \multicolumn{9}{|l|}{ educational characteristics } \\
\hline graduation gap & - & & $-0.40^{* *}$ & $(-4.11)$ & $-0.21^{* *}$ & $(-3.09)$ & $-0.33^{* *}$ & $(-5.17)$ \\
\hline \multicolumn{9}{|l|}{ previous schooling: } \\
\hline higher general & 0.11 & $(0.04)$ & -0.15 & $(-0.50)$ & - & & - & \\
\hline intermediate or higher general & - & & - & & 0.10 & $(0.99)$ & $0.31^{*}$ & $(1.71)$ \\
\hline lower economic & - & & - & & -0.38 & $(-1.47)$ & - & \\
\hline lower technical & - & & - & & - & & -0.13 & $(-1.08)$ \\
\hline intermediate economic & -0.28 & $(-0.74)$ & - & & - & & - & \\
\hline intermediate technical & - & & 0.01 & (0.05) & - & & - & \\
\hline other previous schooling & - & & 0.43 & (1.23) & 0.15 & $(0.58)$ & 0.10 & (0.06) \\
\hline$n$ & 103 & & 117 & & 546 & & 401 & \\
\hline log-likelihood & -152.97 & & -169.01 & & -648.14 & & -536.77 & \\
\hline
\end{tabular}

* $\quad$ significant at the $10 \%$ level

** significant at the $5 \%$ level

For a description of the variables, see Appendix A. 
With regard to intermediate technical schooling, it appears that the graduation gap has a significantly negative effect (at the $5 \%$ level). The probability that a school-leaver will have a lower job level increases as the graduation gap increases. For this particular educational type, the nature of previous schooling is partly relevant. If a school-leaver has completed intermediate or higher general education before entering intermediate technical schooling, the probability that he or she will attain a higher job level increases compared to school-leavers who completed lower general schooling prior to entering their last-attended schooling.

\section{Earnings equation}

In order to examine the relationship between the different components of schooling and the earnings of school-leavers, equations are estimated in which the dependent variable is the natural logarithm of the net monthly income which the school-leaver received at the time of the RUBS survey. The estimated earnings equations are chosen in accordance with the model which has been estimated for the purposes of examining the relationship between the different components of schooling and the allocation of jobs among school-leavers. The earnings equations are estimated by means of ordinary least squares (OLS). The results of the estimated earnings equations are presented in Table 4.

Age has a significantly positive effect on earnings with respect to school-leavers from higher economic education; the older the school-leaver, the higher the net monthly income of that school-leaver. This is probably due to the fact that every worker on the Dutch labour market must receive at least the minimum (youth) wage and that arrangements supporting this are made in collective bargaining contracts. The older one becomes, the higher the (minimum) wage is. The school-leavers who have a temporary job earn less than school-leavers with a permanent job. Furthermore, it should be noted that job level has no significant influence on earnings in the case of this educational type. With regard to the type of education completed before entering higher economic schooling, a school-leaver who completed higher general schooling before attending higher economic education earns less than a school-leaver who completed intermediate general schooling before entering higher economic schooling.

For school-leavers from higher technical schooling, age has a significantly positive effect on earnings. Older school-leavers earn relatively more. School-leavers from this type of schooling with a permanent job earn relatively more than school-leavers with a temporary job. As has already been mentioned, for school-leavers from higher vocational schooling, job level 5 is the reference level. School-leavers who have a job of a lower level earn less than school-leavers with a job at the reference level. However, these dummies do not have a significant effect on earnings. On the other hand, school-leavers with job levels higher than the reference level have 
higher net monthly wages. In the case of school-leavers with jobs at level 6 , this effect is significantly greater than zero.

Table 4. The effects of schooling on net monthly income (t-values in parenthesis)

\begin{tabular}{|c|c|c|c|c|c|c|c|c|}
\hline \multirow{2}{*}{$\begin{array}{l}\text { variables } \\
\text { constant }\end{array}$} & \multicolumn{2}{|c|}{$\begin{array}{l}\text { higher } \\
\text { economic } \\
\text { schooling }\end{array}$} & \multicolumn{2}{|c|}{$\begin{array}{l}\text { higher } \\
\text { technical } \\
\text { schooling }\end{array}$} & \multicolumn{2}{|c|}{$\begin{array}{l}\text { intermediate } \\
\text { economic } \\
\text { schooling }\end{array}$} & \multicolumn{2}{|c|}{$\begin{array}{l}\text { intermediate } \\
\text { technical } \\
\text { schooling }\end{array}$} \\
\hline & $7.10^{* *}$ & $(26.92)$ & $6.89^{* *}$ & (33.51) & 5.63 & $(32.22)$ & $6.83^{* *}$ & $(49.41)$ \\
\hline \multicolumn{9}{|l|}{ personal characteristics } \\
\hline region & - & & - & & $-0.11^{* *}$ & $(-5.84)$ & -0.06 & $(-1.32)$ \\
\hline age & $0.02^{* *}$ & $(1.98)$ & $0.03^{* *}$ & $(3.70)$ & $0.08^{* *}$ & (9.71) & $0.03^{* *}$ & (4.32) \\
\hline sex & 0.02 & $(0.58)$ & -0.03 & $(-0.51)$ & -0.01 & $(-0.55)$ & 0.02 & $(0.31)$ \\
\hline \multicolumn{9}{|l|}{ job characteristics } \\
\hline temporary job & $-0.06^{*}$ & $(-1.70)$ & $-0.07^{* *}$ & $(-2.43)$ & 0.01 & $(0.72)$ & -0.04 & $(-1.34)$ \\
\hline job level 1 & - & & - & & $-0.19^{* *}$ & $(-3.00)$ & $-0.20^{* *}$ & $(-2.87)$ \\
\hline job level 2 & - & & - & & $-0.11^{*}$ & $(-3.21)$ & 0.00 & 10.05 \\
\hline job level 3 & - & & - & & $-0.06^{* *}$ & $(-2.99)$ & 0.01 & 10.29 \\
\hline job levels $1,2 \& 3$ & 0.01 & $(0.21)$ & -0.05 & $(-1.28)$ & - & & - & \\
\hline job level 4 & -0.03 & $(-0.64)$ & -0.01 & $(-0.38)$ & - & & - & \\
\hline job level 5 & - & & - & & -0.00 & $(-0.02)$ & 0.03 & 10.93 \\
\hline job level 6 & 0.06 & $(0.96)$ & $0.07^{*}$ & (1.84) & - & & - & \\
\hline job level 7 & 0.08 & $(1.30)$ & 0.03 & $(0.76)$ & - & & - & \\
\hline job levels $6 \& 7$ & - & & - & & 0.05 & (0.69) & $0.10^{* *}$ & (2.10) \\
\hline \multicolumn{9}{|l|}{ educational characteristics } \\
\hline graduation gap & - & & $-0.03^{*}$ & $(-1.96)$ & $-0.03^{* *}$ & $(-2.35)$ & $-0.06^{* *}$ & $(-3.89)$ \\
\hline \multicolumn{9}{|l|}{ previous schooling: } \\
\hline higher general & $-0.09^{*}$ & $(-1.94)$ & -0.04 & $(-1.17)$ & - & & - & \\
\hline intermediate or higher general & - & & - & & $0.04^{* *}$ & $(2.01)$ & 0.00 & $(0.10$ \\
\hline lower economic & - & & - & & 0.00 & $(0.01)$ & - & \\
\hline lower technical & - & & - & & - & & -0.02 & $(-0.68)$ \\
\hline intermediate economic & -0.05 & $(-0.95)$ & - & & - & & - & \\
\hline intermediate technical & - & & -0.04 & $(-1.14)$ & - & & - & \\
\hline other previous schooling & - & & -0.02 & $(-0.53)$ & 0.05 & (0.99) & 0.06 & $(1.46)$ \\
\hline $\mathrm{n}$ & 103 & & 117 & & 546 & & 401 & \\
\hline adjusted $R^{2}$ & 0.08 & & 0.26 & & 0.28 & & 0.16 & \\
\hline
\end{tabular}

* $\quad$ significant at the $10 \%$ level

* * significant at the $5 \%$ level

For a description of the variables, see Appendix A.

In the case of higher technical schooling, the graduation gap variable was included in the estimations; this variable is significantly (at the $10 \%$ level) less than zero. This implies that, in 
the case of higher technical education, the longer the period of time between interrupting education and the point at which the diploma would potentially have been obtained from the educational type concerned, the lower the net monthly income of the school-leaver.

The influence of region is negative in the case of both intermediate economic and intermediate technical education. However, this effect is only significant for school-leavers from intermediate economic education. Therefore, school-leavers from intermediate economic schooling originating from the economic centre of the Netherlands earn relatively more than those school-leavers not resident there. This regional difference probably reflects the tighter labour market situation in the economic centre of the Netherlands. For both educational types of the intermediate level distinguished, age has a significantly positive effect. The older the school-leaver from these educational types, the higher the net monthly income.

Job level has a significant influence on earnings in the case of both school-leavers from intermediate economic schooling and school-leavers from intermediate technical schooling. School-leavers from economic education who have jobs of a level lower than their reference job level - this being job level 4 - earn less than school-leavers with jobs at the reference level. The parameters of these variables are significantly less than zero and the values of these coefficients ascend. The effect of a job at level 6 or 7 is positive. However, this dummy does not have a significant influence on earnings. The parameter for the variable 'job level 5' is negative. This would indicate that school-leavers with jobs at these levels earn lower wages than school-leavers with jobs whose level is the reference level. Nevertheless, this effect is not significant.

In the case of intermediate technical education, the effect of 'job level 1' is significantly less than zero. This means that school-leavers with jobs at the lowest level have lower net monthly incomes than school-leavers with jobs at level 4. The parameters of the variables 'job level 2' and 'job level 3' are positive. However, these effects are not significant. Furthermore, Table 4 shows that the effect of the dummies with respect to jobs of a level higher than the reference level is positive. However, only the parameter of the variable indicating that a school-leaver has a job at level 6 or 7 is significant. School-leavers with jobs at level 6 or 7 have a higher net monthly income than school-leavers with jobs at level 4 . Finally, it can be noted that the values of the coefficients of the job level variables are ascending with respect to this educational type.

For both educational types of an intermediate level distinguished, the coefficient for the variable 'graduation gap' is significantly less than zero. This implies that the longer the period of time between interrupting education and the point at which the diploma would potentially have been obtained from the last-attended school, the lower the net monthly wage is. 
In the case of intermediate economic schooling, the educational type which the school-leaver completed before his or her last-attended education has a certain amount of influence on the earnings of the school-leaver concerned. A school-leaver who completed general education of an intermediate or higher level has a higher net monthly income than a school-leaver who completed lower general education before attending intermediate economic education.

Finally, it can de remarked that with respect to higher economic education, the variables included only account for a small part $(8 \%)$ of the variance. In the case of higher technical education, the variance accounted for by the variables included amounts to $26 \%$. For intermediate vocational schooling, the variables account for a larger part of the variance than in the corresponding branches of study of a higher level. The variables included account for respectively $28 \%$ and $16 \%$ of the variance with respect to intermediate economic and technical education. 


\section{SUMMARY AND CONCLUSIONS}

The aim of this study was to examine whether diplomas have a dominant effect on both job allocation and income or whether this effect gradually increases as each additional year of schooling is attended. If the latter is indeed the case, the human capital hypothesis is supported. This implies that the difference in income or job levels among graduates and dropouts from the last year of schooling must be minor. If, on the other hand, this difference is considerable, there is a strong tendency towards the acceptance of the screening theory. In this case, diplomas have a dominant effect on job level and earnings. A third labour market theory, the labour queue hypothesis, was also tested. This theory is supported if the incomes of employed school-leavers can be explained by the job levels of these school-leavers and not by the human capital accumulated.

This paper focused on school-leavers from four types of education: higher economic schooling, higher technical schooling, intermediate economic schooling and intermediate technical schooling. In the case of each educational type, two equations were estimated in order to examine the effects of diplomas on the incomes and job levels of employed school-leavers. A job allocation and an earnings equation were subsequently estimated. This was based on the fact that individual earnings are firstly determined by the allocation of jobs to individuals and subsequently by the payment which individuals receive within these jobs.

With regard to personal characteristics, it can be observed that age has a significantly positive influence on net monthly earnings in the case of all four educational types distinguished in this paper. This can probably be accounted for by the fact that the minimum wage which every worker on the Dutch labour market must receive, is stipulated by the Minimum Wage Act. The older one becomes, the higher the legal minimum wage. The effect on job level is significantly negative in the case of school-leavers from higher technical education and is significantly positive in the case of school-leavers from intermediate economic schooling. The remaining personal characteristics (sex and region) only have an influence in the case of school-leavers from intermediate economic schooling.

The group of variables representing job characteristics consists, on the one hand, of the variable relating to having a temporary job, which is present in the job level and the earnings equation, and, on the other hand, of the job levels of the school-leavers included only in the earnings equation. The fact that a school-leaver has a temporary job has a negative effect on job level in the case of school-leavers from intermediate economic education. This variable also has a negative effect on net monthly wages with respect to school-leavers from higher technical and economic schooling. 
The labour queue theory was tested by including the job level variables in the earnings equation. With respect to the effect of job levels on net monthly wages, the estimation results show that, in the case of each educational type distinguished with the exception of higher economical schooling, several job levels have a significant influence on earnings. Of these variables which have a significant influence, the job levels lower than the reference level have a negative influence and the job levels higher than the reference level have a positive influence. In other words, the job level variables which have a significant influence have values (positive or negative) which correspond with those expected. This implies that earnings are partly explained by job levels. Since school-leavers attempt, through obtaining good jobs (of a relatively high level), to earn a good net monthly wage, the labour queue theory is (partially) supported in the case of the school-leavers from the four educational types distinguished in this study.

The third group of explanatory variables consists of the educational type completed before entering last-attended schooling and the length of time between interrupting education and the point at which the diploma would potentially have been obtained from last-attended schooling. In this study the variable 'graduation gap' attempts to test the relevance of the human capital or the screening theory. According to the screening theory, diplomas have a dominant effect on job levels and earnings, whereas the human capital theory states that schooling has a gradual effect. The variable 'graduation gap' has, in the case of all educational types distinguished with the exception of higher economic schooling, a significantly negative influence. This implies that the longer the period of time between interrupting education and the point at which the diploma would potentially have been obtained from last-attended schooling, the lower the job level and net monthly earnings. One might therefore conclude from this that, with regard to the schoolleavers examined in this paper, the human capital theory is supported and the screening and signaling theories are rejected.

With regard to the educational type completed by school-leavers before entering last-attended schooling, the estimation results show that there is only a slight effect on both net monthly wages and job levels. The differences between school-leavers resulting from the educational type a school-leaver completed prior to entering their last-attended schooling, disappear once the diploma of the last-attended school is obtained. It might be concluded from this that, with regard to the educational career of the school-leavers, the last-completed schooling has the largest influence on incomes and job levels. 


\section{REFERENCES}

Greene, W.H. (1990), Econometric analysis, MacMillan, New York.

Groot, W., H. Oosterbeek (1990), Does it pay to take the shortest way?: incidence and labor market consequences of class repetitions, dropping out and inefficient routing in education, Research memorandum 9013, University of Amsterdam, Amsterdam.

Hartog, J. (1983), To graduate or not: does it matter?, Economic Letters, volume 12, pp. 193199.

Hartog, J. (1988), An ordered response model for allocation and earnings, Kyklos, volume 41 , pp. 113-141.

Huijgen, F. (1989), De kwalitatieve structuur van de werkgelegenheid in Nederland. Deel III: bevolking in loondienst en functiestructuur in 1977 en 1985, OSA-voorstudie V33, 'sGravenhage

Maddala, G.S. (1983), Limited-dependent and qualitative variables in econometrics, Cambridge University Press, Cambridge.

Schultz, T.W. (1961), Investment in human capital, American Economic Review, volume 51, pp. 1-17.

Spence, O.F. (1973), Job market signaling, Quarterly Journal of Economics, pp. 355-374.

Stiglitz, J.E. (1975), The theory of screening, education and distribution of income, American Economic Review, volume 66, pp. 283-300.

Thurow, L.C. (1979), A job competition model, in: Piore (ed.), Unemployment and inflation: institutionalist and structuralist views, White Plains, New York, pp. 17-32. 


\section{APPENDIX A: DESCRIPTION OF THE VARIABLES}

personal characteristics

region

age

sex

ethnic minority

job characteristics

self-employed

temporary job

earnings

job level

job level 1

job level 2

job level 3

job level 4

job level 5

job level 6

job level 7

job levels 1,2 \& 3

job levels $6 \& 7$

over-education

educational characteristics

no diploma

graduation gap

previous schooling:

lower general (MAVO)

intermediate general (HAVO)

higher general (VWO)

intermediate or higher general

lower economic (LEAO)

lower technical (LTS)

intermediate economic (MEAO)

intermediate technical (MTS)

other previous schooling
$=1$, if school-leaver is not resident in the economic centre of the Netherlands

$=\quad$ age of the school-leaver in years

$=1$, if school-leaver is a female

$=1$, if school-leaver belongs to an ethnic minority

$=1$, if school-leaver is self-employed

$=1$, if school-leaver has a temporary job

$=$ net monthly income

$=\quad$ level of the job of the school-leaver

$=1$, if school-leaver has a job at level 1

$=1$, if school-leaver has a job at level 2

$=1$, if school-leaver has a job at level 3

$=1$, if school-leaver has a job at level 4 (reference level for intermediate economic and technical schooling)

$=1$, if school-leaver has a job at level 5 (reference level for higher economic and technical schooling)

$=1$, if school-leaver has a job at level 6

$=1$, if school-leaver has a job at level 7

$=1$, if school-leaver has a job at level 1, 2 or 3 (only for higher economic and technical schooling)

$=1$, if school-leaver has a job at level 6 or 7 (only for intermediate economic and technical schooling)

$=1$, if the school-leaver is over-educated

$=1$, if the school-leaver does not have a diploma from the lastattended school

$=$ the length of time (expressed in years) between interrupting education and the point at which the diploma would potentially have been obtained from last-attended schooling

$=1$, if the school-leaver completed lower general schooling before his or her last-attended school (reference category for intermediate economic and technical schooling)

$=1$, if the school-leaver completed intermediate general schooling before his or her last-attended school (reference category for higher economic and technical schooling)

$=1$, if the school-leaver completed higher general schooling before his or her last-attended school

$=1$, if the school-leaver completed higher or intermediate general schooling before his or her last-attended school (only for intermediate economic and technical schooling)

$=1$, if the school-leaver completed lower economic schooling before his or her last-attended school

$=1$, if the school-leaver completed lower technical schooling before his or her last-attended school

$=1$, if the school-leaver completed intermediate economic schooling before his or her last-attended school

$=1$, if the school-leaver completed intermediate technical schooling before his or her last-attended school

$=1$, if the school-leaver completed any other type of education before his or her last-attended school 


\section{APPENDIX B: ORDERED PROBIT MODEL}

In the ordinal probit model, $m$ categories and $n$ observations are distinguished (see also Maddala, 1983 and Hartog, 1988). Therefore, a set of constants $\alpha_{i}$ is defined, so that:

$$
\alpha_{0}<\alpha_{1}<\alpha_{2}<\ldots<\alpha_{m} \quad \alpha_{m}=+\infty
$$

The underlying response model is described as:

$Y_{i}=\beta^{\prime} x_{i}+u_{i} \quad(i=1,2, \ldots, n)$

where $\boldsymbol{Y}_{i} \quad$ is the response variable;

$x_{i} \quad$ is a set of explanatory variables;

$\beta \quad$ is a vector of unknown coefficients;

$u_{i} \quad$ is the residual.

The error term $u_{i}$ is normally distributed, thus $u_{i} \sim \operatorname{IN}(0,1)$.

$Y_{i}$ is not observed, but the category to which it belongs is known. It belongs to the th category if:
$\alpha_{j-1}<Y_{i} \leq \alpha_{j}$
$(j=1,2, \ldots, m)$

A set of ordinal variables is defined:

$Z_{i j}= \begin{cases}1 & \text { if } Y_{i} \text { falls in the jth category } \\ 0 & \text { in other cases }\end{cases}$

with $i=1,2, \ldots, n$ and $j=1,2, \ldots, m$ 
$\operatorname{Prob}\left(Z_{i j}=1\right)=\Phi\left(\alpha_{j}-\beta^{\prime} x_{i}\right)-\Phi\left(\alpha_{j-1}-\beta^{\prime} x_{i}\right)$

where $\Phi$ is the standard normal distribution function.

The likelihood for the model is:

$L=\prod_{i=1}^{n} \prod_{j=1}^{m}\left[\Phi\left(\alpha_{j}-\beta^{\prime} x_{i}\right)-\Phi\left(\alpha_{j-1}-\beta^{\prime} x_{i}\right)\right]^{z_{i j}}$

and the log-likelihood function is:

$\log L=\sum_{i=1}^{n} \sum_{j=1}^{m} Z_{i j} \log \left[\Phi\left(\alpha_{j}-\beta^{\prime} x_{i}\right)-\Phi\left(\alpha_{j-1}-\beta^{\prime} x_{i}\right)\right]$ 